University of Nebraska - Lincoln

DigitalCommons@University of Nebraska - Lincoln

Genetic and hybridization evidence confirms that a geographic population of Gonatocerus morrilli (Hymenoptera: Mymaridae) from California is a new species: Egg parasitoids of the glassywinged sharpshooter Homalodisca coagulata (Homoptera: Cicadellidae)

Jesse H. de León

United States Department of Agriculture

Walker A. Jones

United States Department of Agriculture

Mamoudou Sétamou

United States Department of Agriculture

David J. W. Morgan

California Department of Food and Agriculture

Follow this and additional works at: https://digitalcommons.unl.edu/usdaarsfacpub

Part of the Agricultural Science Commons

de León, Jesse H.; Jones, Walker A.; Sétamou, Mamoudou; and Morgan, David J. W., "Genetic and hybridization evidence confirms that a geographic population of Gonatocerus morrilli (Hymenoptera: Mymaridae) from California is a new species: Egg parasitoids of the glassy-winged sharpshooter Homalodisca coagulata (Homoptera: Cicadellidae)" (2006). Publications from USDA-ARS / UNL Faculty. 325.

https://digitalcommons.unl.edu/usdaarsfacpub/325

This Article is brought to you for free and open access by the U.S. Department of Agriculture: Agricultural Research Service, Lincoln, Nebraska at DigitalCommons@University of Nebraska - Lincoln. It has been accepted for inclusion in Publications from USDA-ARS / UNL Faculty by an authorized administrator of DigitalCommons@University of Nebraska - Lincoln. 


\title{
Genetic and hybridization evidence confirms that a geographic population of Gonatocerus morrilli (Hymenoptera: Mymaridae) from California is a new species: Egg parasitoids of the glassy-winged sharpshooter Homalodisca coagulata (Homoptera: Cicadellidae)
}

\author{
Jesse H. de León ${ }^{\mathrm{a}, *}$, Walker A. Jones ${ }^{\mathrm{a}, 1}$, Mamoudou Sétamou ${ }^{\mathrm{a}}$, David J.W. Morgan ${ }^{\mathrm{b}}$ \\ ${ }^{a}$ United States Department of Agriculture, Agricultural Research Service, Subtropical Agricultural Research Center, Beneficial Insects Research Unit, \\ 2413 E. Highway 83, Weslaco, TX 78596, USA \\ ${ }^{\mathrm{b}}$ California Department of Food and Agriculture, Mount Rubidoux Field Station, Riverside, CA 92501, USA
}

Received 26 October 2005; accepted 15 March 2006

Available online 2 May 2006

\begin{abstract}
We investigated the differentiation and reproductive isolation among different geographic populations of Gonatocerus morrilli, egg parasitoids of the glassy-winged sharpshooter (Homalodisca coagulata), to confirm previous observations that there may exist a cryptic species complex or a new species. Two mitochondrial genes [cytochrome oxidase subunits I (COI) and II (COII)] and the internal transcribed spacer region 2 (ITS2) of several individuals per population were sequenced. G. morrilli populations from Texas (TX), Florida (FL), California (CA), and an outgroup ( $G$. ashmeadi) were analyzed. For comparison, a population from Argentina (G. annulicornis) morphologically similar to G. morrilli was also included. For all three sequence fragments, percentage sequence divergence (\%D) demonstrated that both the TX and FL populations (TX/FL) were closely related and therefore determined to be the same species; in contrast, the $\% \mathrm{D}$ between TX/FL and CA fell within the range of the outgroup, making the CA population a new species or sp. n. Neighbor-joining distance trees also clustered the TX/FL and CA populations or species into two well supported distinctive clades. The near G. morrilli sp. n. was more closely related to $G$. annulicornis than to the TX/FL species. Mating studies demonstrated that the populations or species from CA and TX were reproductively incompatible, producing no female offspring in both direct and reciprocal crosses; whereas, the heterogamic crosses between TX and FL produced fertile offspring and relative compatibility indices similar to the homogamic crosses. Unidirectional cytoplasmic incompatibility was ruled out as a cause for the lack of reproduction since both males and females were infected in equal portions with Wolbachia.
\end{abstract}

(c) 2006 Elsevier Inc. All rights reserved.

Keywords: Gonatocerus morrilli; Egg parasitoids; Biological control; Pierce's disease; Homalodisca coagulata; Phylogenetics; DNA fingerprinting

\section{Introduction}

Accurate identification of natural enemies is critical to the success of classical biological control programs, as it is

\footnotetext{
* Corresponding author. Fax: +1 9569694888.

E-mail address: jhleon@weslaco.ars.usda.gov (J.H. de León).

${ }^{1}$ Present address: European Biological Control Laboratory, United States Department of Agriculture, Agricultural Research Service, Campus International de Baillarguet, CS90013 Montferrier sur Lez, 34988 St. Gely du Fesc CEDEX, France.
}

essential for (1) selecting the most suitable natural enemy, (2) evaluating establishment, dispersal, and efficacy of natural enemies, and (3) improving mass production. Lack of proper identification procedures has affected several projects (Gordh and Beardsley, 1999; Löhr et al., 1990; Messing and Aliniazee, 1988; Miller and Rossman, 1995; Narang et al., 1993; Rosen, 1977; Schauff and LaSalle, 1998; Unruh and Woolley, 1999). Phylogenetics has become a widespread approach for delineating and identifying morphologically similar or cryptic species. In addition, it can identify the possible causes of divergence 
(Avise, 2000; MacDonald and Loxdale, 2004; Narang et al., 1993; Rosen, 1977; Schauff and LaSalle, 1998; Unruh and Woolley, 1999). The approach has also been utilized to identify the geographic origins and mechanisms of spread of invasive species (Avise, 2000; Brown, 2004; Roderick, 2004).

Gonatocerus morrilli (Howard) (Hymenoptera: Mymaridae) is an egg parasitoid of Homalodisca coagulata (Say) (Homoptera: Cicadellidae: Proconiini), the glassy-winged sharpshooter (GWSS) (Triapitsyn et al., 1998; Turner and Pollard, 1959). This primary egg parasitoid species is common in the southern United States and Mexico (Huber, 1998). A biological control program is currently in progress in California (CA) against the GWSS (CDFA, 2003), a xylem feeding leafhopper that is a serious economic pest that transmits a strain of Xylella fastidiosa (Wells), a bacterium that causes Pierce's disease in grapevines (Vitis vinifera $\mathrm{L}$. and Vitis labrusca L.), as well as diseases in many other plants (Hopkins, 1989; Hopkins and Mollenhauer, 1973). H. coagulata is native to the southern United States, ranging from Florida (FL) to Texas (TX) and northeastern Mexico (Brlansky et al., 1983; Nielson, 1968; Redak et al., 2004; Turner and Pollard, 1959; Young, 1958). Within the last 20 years, this insect has established and spread in southern CA, where it poses a serious threat to the $\$ 33$ billion wine and table grape industry (Sorensen and Gill, 1996). However, prior to the introduction and spread of GWSS in CA, G. morrilli was recovered from eggs of the smoke-tree sharpshooter $H$. liturata (Ball), a close relative of the GWSS (Bursk and Redak, 2003; Redak et al., 2004; Varela et al., 2001). Presently, this parasitoid also attacks eggs of the GWSS in CA.

Correct identification of the pest is also extremely important in biological control. Geographic populations of the same species may differ in relevant biological characteristics of importance to biological control. In addition, pin-pointing the native origin of an exotic pest is crucial for collection of natural enemies in the native range of the pest (Brown, 2004; Narang et al., 1993; Roderick, 2004; Rosen, 1977; Unruh and Woolley, 1999). Studies by de León and Jones (2004) and de León et al. $(2003,2004 a)$ demonstrated that the GWSS that invaded CA is of TX origin, but more than one founding event occurred. Their data also showed that GWSS populations in the US were genetically distinct, clustering into two main groups or clades, a 'southeastern' and a 'southwestern and western' clade. Similarly, molecular studies of G. morrilli populations from CA and TX using inter-simple sequence repeat-polymerase chain reaction (ISSR-PCR) DNA fingerprinting and amplification of the internal transcribed spacer 2 region (ITS2) showed that these populations were highly differentiated $\left(G_{\mathrm{ST}}=0.92\right)$ with restricted gene flow (de León et al., 2004b). These results strongly suggested that G. morrilli exists in nature as a cryptic species complex or that a new species had been identified. Furthermore, the different sizes of the ITS2 amplification fragments between the geographic populations raised concerns over the reproductive compatibility of these populations and its implications in a biological control program. The ITS regions have been used extensively in the examination of the taxonomic status of species and for diagnostic purposes (reviewed in Collins and Paskewitz, 1996; Hackett et al., 2000).

The objective of the present study was to confirm whether G. morrilli exists in nature as a cryptic species complex or whether a new species was identified. We investigated the differentiation and reproductive isolation among geographic populations. We extended our previous observations by implementing a phylogenetic approach by sequencing two mitochondrial genes [cytochrome oxidase subunit I and II genes (COI) and (COII)] and one ribosomal DNA spacer region fragment (ITS2). Reproductive compatibility studies were performed with populations of G. morrilli from three origins: CA, FL, and TX. Reproductive isolation is an important criterion for the determination of the systematic status of sibling or cryptic species (Rosen, 1977). A population morphologically similar to G. morrilli from Argentina, South America [G. annulicornis (Ogloblin)] was also included for comparison purposes. In addition, G. morrilli populations were tested for the presence of the endosymbiotic bacterium, Wolbachia pipientis with a newly developed nested or 2ndround PCR assay targeting the 16S rRNA partial gene. The presence of Wolbachia has been shown to induce reproductive alterations, such as, cytoplasmic incompatibility in a wide range of arthropods (Barr, 1980; Breeuwer and Werren, 1990; Stouthamer et al., 1993; reviewed in Werren, 1997).

\section{Materials and methods}

\subsection{Insect collection}

Gonatocerus morrilli samples were collected from GWSS egg masses: two populations were from CA, Orange (OrgCoCA) and San Diego (San Marcos, CA; SMCA) counties, three were from Hidalgo county, TX (Weslaco; WTX1, WTX2, and WTX3), collected five months apart in 2003, and one population was from Quincy, FL (Gadsden county) collected by Christopher Tipping of the University of Florida. Gonatocerus ashmeadi (Girault) were collected as previously described (de León and Jones, 2005) and were utilized as an outgroup. A population of wasps from San Miguel de Tucumán, Tucumán Province, Argentina [G. annulicornis (Ogloblin) (8th generation)] classified as morphologically similar to G. morrilli was also included for comparison. This egg parasitoid was imported to the USDA, APHIS, Arthropod Quarantine Facility, Edinburg, TX. Serguei Triapitsyn, a taxonomist, from the University of California, Riverside, identified this egg parasitoid. M04005 (Code TV-4/species \#4) was the unique code associated with this imported colony. Specimens were then shipped to Weslaco in 95\% non-denatured ethanol. Morphological analyses (based primarily on the propodeal carinae characters) plus the current molecular data of G. morrilli has led to the description of the G. morrilli population from California as a 'new species' or 'sp. n.' by Serguei Triapitsyn. This new species belongs to the morrilli subgroup of the ater 
species group of Gonatocerus. This species was previously misidentified as being G. morrilli. The morphological work along with a review of several sharpshooter egg parasitoids is 'in review' and the name of the new species will be released upon publication of the manuscript (S. Triapitsyn, personal communication). Voucher specimens of egg parasitoids used in the current study were deposited in the Entomology Research Museum, University of California, Riverside (UCRC).

\subsection{Genomic DNA isolation}

Total genomic DNA was extracted according to standard methods (Sambrook and Russell, 2001) and as previously described (de León et al., 2004b; de León and Jones, 2005). Individual wasps were homogenized on ice in $1.5 \mathrm{ml}$ microfuge tubes in $60 \mu \mathrm{l}$ of lysis buffer [ $10 \mathrm{mM}$ Tris- $\mathrm{HCl}$ (pH 7.5), $1 \mathrm{mM}$ EDTA ( $\mathrm{pH} 7.5$ ), and $1 \%$ IGEPAL (CA630)] with two 20-s burst with 10 min intervals on ice (Pellet Pestle Motor, Bel-Art Products, Pequannock, NJ). To avoid cross contamination between samples, a sterile plastic pestle was used per individual insect. The final DNA pellet was resuspended in $61 \mu \mathrm{l}$ of TE [Tris- $\mathrm{HCl}(\mathrm{pH} 7.5), 1 \mathrm{mM}$ EDTA (pH 7.5)]. To confirm for the presence of genomic DNA, amplification reactions were performed with $1 \mu$ of stock DNA and 28S primers at an annealing temperature of $65^{\circ} \mathrm{C}$ (forward: 5'-CCCTGTTGAGCTTGACTCTAGT CTGGC-3' and reverse: $5^{\prime}$-AAGAGCCGACATCGAAGG ATC-3') (Werren et al., 1995) with $1.5 \mathrm{mM} \mathrm{MgCl}_{2}$ and the amplification conditions described below.

\subsection{ISSR-PCR DNA Fingerprinting}

ISSR-PCR amplification reactions are described in previous work (de León and Jones, 2004, 2005; de León et al., 2004b). The reactions were performed with the 5'anchored primer $\mathrm{HVH}(\mathrm{TG})_{7} \mathrm{~T}$ (Zietkiewicz et al., 1994), where $\mathrm{H}=\mathrm{A} / \mathrm{T} / \mathrm{C}$ and $\mathrm{V}=\mathrm{G} / \mathrm{C} / \mathrm{A}$. The reactions were performed in a final volume of $20 \mu \mathrm{l}$ with the following components: 1X PCR buffer [ $50 \mathrm{mM} \mathrm{KCl}, 20 \mathrm{mM}$ Tris- $\mathrm{HCl}$ (pH 8.4), $1.5 \mathrm{mM} \mathrm{MgCl}_{2}$, and $0.01 \%$ gelatin], $0.25 \mathrm{mM}$ deoxynucleotide triphosphates, $0.25 \mu \mathrm{M}$ ISSR primer, $1.0 \mu \mathrm{l}$ of stock genomic DNA, and $0.05 \mathrm{U} / \mu \mathrm{l}$ Taq DNA Polymerase (New England Biolabs, Beverly, MA). The cycling parameters were as follows: 1 cycle at $94{ }^{\circ} \mathrm{C}$ for $2 \mathrm{~min}$ followed by 45 cycles at $94^{\circ} \mathrm{C}$ for $1 \mathrm{~min}, 56^{\circ} \mathrm{C}$ for $1 \mathrm{~min}$, and $72^{\circ} \mathrm{C}$ for $2 \mathrm{~min}$. Reactions were optimized for amount of genomic DNA, annealing temperature, $\mathrm{MgCl}_{2}$ concentration, and cycle number. Negative control reactions were performed in the absence of genomic DNA. Amplification products were loaded onto $2 \%$ agarose gels and submitted to electrophoresis in $1 \times \mathrm{TBE}$ buffer ( $90 \mathrm{mM}$ Tris-borate and $2 \mathrm{mM}$ EDTA) in the presence of $0.2 \mu \mathrm{g} / \mathrm{ml}$ ethidium bromide. Gels were photographed with the Chemi Doc System and markers/bands were scored via the Quantity One Software ${ }^{\mathrm{TM}}$ (Bio-Rad Laboratories, Hercules, CA).

\subsection{Amplification and sequencing of partial mitochondrial} cytochrome oxidase subunit I (COI) and II (COII) genes

The general primers C1-J-1718 (forward: 5'-GGAG GATTTGGAAATTGATTAGTTCC-3') and C1-N-2191 (reverse: 5'-CCCGGTAAAATTAAAATATAAACTTC-3') of Simon et al. (1994) were utilized $\left(T_{\mathrm{m}} 58^{\circ} \mathrm{C} ; 2.0 \mathrm{mM} \mathrm{MgCl}_{2}\right.$; 35 cycles) to amplify the COI partial gene from egg parasitoids. PCR products were subcloned with the TOPO Cloning Kit (Invitrogen Life Technologies, Carlsbad, CA), plasmid minipreps were prepared by the QIAprep Spin Miniprep Kit (Qiagen Inc., Valencia, CA), and sequencing was performed by GENEWIZ INC (North Brunswick, NJ). GenBank Accession Nos. for the G. morrilli COI partial genes are: TX, AY971849-AY971853; FL, AY971854-AY971857; CA, AY971858-AY971865; G. ashmeadi COI Accession Nos. are AY971869-AY971871; and G. annulicornis COI Accession Nos. are AY971866-AY971868. The following primers TL2J-3034 (forward: 5-'AATATGGCAGATTAGTGCA-3') (Loxdale and Lushai, 1998) and C2-N-3661 (reverse: 5'-CC ACAAATTTCTGAACATTGACCA-3') (Simon et al., 1994) $\left(T_{\mathrm{m}} 60^{\circ} \mathrm{C} ; 2.0 \mathrm{mM} \mathrm{MgCl} 2 ; 40\right.$ cycles $)$ were utilized to amplify the COII partial gene. GenBank Accession Nos. for the G. morrilli COII partial genes are: TX, AY997654 AY997658; FL, AY997659-AY997661; CA, AY997662AY997670; G. ashmeadi, AY997675-AY997677; and G. annulicornis, AY997671-AY997674.

\subsection{Internal transcribed spacer region 2 (ITS2) amplification and sequencing}

The ITS2 rDNA fragment was amplified with the following standard primers, 5.8S-F (forward), 5'-TGTGAACTG CAGGACACATGAAC- $3^{\prime}$ and 28S-R (reverse), 5'-AT GCTTAAATTTAGGGGGTA-3' (Porter and Collins, 1991) as described in de León et al. (2004a,b). The amplification reactions were performed as with ISSR-PCR above. The cycling parameters were as follows: 1 cycle for $3 \mathrm{~min}$ at $94^{\circ} \mathrm{C}$ followed by 45 cycles at $94^{\circ} \mathrm{C}$ for $20 \mathrm{~s}, 45^{\circ} \mathrm{C}$ for $20 \mathrm{~s}$, and $72^{\circ} \mathrm{C}$ for 60 s. GenBank Accession Nos. for the G. morrilli ITS2 rDNA fragments are: TX, DQ002409-DQ002415; FL, DQ002416-DQ002419; CA, DQ002424-DQ002430. G. ashmeadi ITS2 Accession Nos. are DQ002431-DQ002433; and $G$. annulicornis ITS2 Accession Nos. are DQ002420 DQ002423.

\subsection{DNA sequence analysis}

The DNA sequencing software program Sequencher (Gene Codes Corp., Ann Arbor, MI) was utilized to process the raw sequences and the program DNAStar (DNAStar, Inc.; Madison, WI) that includes the ClustalV program (Higgins and Sharp, 1988) was used to calculate percentage divergence $(\% \mathrm{D})$, as measured as a function of genetic distance. The alignment program ClustalX (Thompson et al., 1997) in combination with the program PAUP $4.0 \mathrm{~b} 10$ (Swofford, 2002) were utilized for alignment, bootstrapping 
(as percentage of 1000 replications) (Felsenstein, 1985), and reconstruction of neighbor-joining trees utilizing the uncorrected 'p' genetic distance (Saitou and Nei, 1987). Analyses were also performed with the Jukes-Cantor genetic distance parameter (Jukes and Cantor, 1969), which showed no significant differences to the uncorrected 'p' genetic distance analyses. Mitochondrial DNA sequences were translated into amino acid sequences by using the invertebrate mitochondrial code with the computer program EMBOSS Transeq (http://www.ebi.ac.uk/emboss/transeq/index.html?).

\subsection{Reproductive compatibility procedure}

Three colonies of G. morrilli originating from TX, FL, and CA, respectively, were maintained on eggs of GWSS at the Beneficial Insects Research Unit, Weslaco, TX under a controlled environment at $25 \pm 2{ }^{\circ} \mathrm{C}, 50-60 \% \mathrm{RH}$ and a L12:12D photoperiod. Stock cultures of G. morrilli from TX and FL were initiated from parasitized egg masses of GWSS collected from Texas mountain laurel or citrus leaves, while the G. morrilli culture from CA was initiated from parasitized egg masses of $H$. liturata. Upon emergence, all adult parasitoids were kept in glass vials and fed with $50 \%$ honey solution (vol:vol). For the experiments, isofemale lines of G. morrilli were started from one female by exposing eggs of GWSS laid on cowpea (Vigna unguiculata) plants as hosts. These isofemales of G. morrilli of different origins were used in the crossing studies. To ensure uniform age of parasitoids for the experiments, mated G. morrilli females were offered 1 day-old eggs of GWSS on excised cowpea leaves maintained in aquapics (Sétamou and Walker, 2005). GWSS eggs were exposed for $24 \mathrm{~h}$ and subsequently checked daily for parasitoid emergence. Upon emergence, each virgin parasitoid was immediately isolated in a glass vial.

To evaluate the mating compatibility between G. morrilli from TX and the other two geographic regions, mating crosses between males and isofemale lines from TX and each of the two other regions were made. Since eggs of GWSS from TX were used as hosts, the cross between virgin males and virgin isofemales from TX was used as control. Direct crosses between a virgin female from TX and a virgin male from $\mathrm{CA}$ or $\mathrm{FL}\left(\$ \mathrm{TX} \times{ }^{\mathrm{T}} \mathrm{CA}\right.$ and $\left.\uparrow \mathrm{TX} \times{ }^{\top} \mathrm{FL}\right)$ and their reciprocal crosses $\left(+\mathrm{CA} \times{ }^{\mathrm{T}} \mathrm{TX}\right.$ and $+\mathrm{FL} \times{ }^{\top} \mathrm{TX}$ ) were evaluated. Ten to 22 crosses (direct or reciprocal) were made per combination. Individual pairs were carefully monitored and once mating had occurred, the female was isolated and used to parasitize GWSS eggs. Each female was offered one egg mass (18-25 eggs) maintained on an excised cowpea leaf for parasitization. Egg masses were removed after $24 \mathrm{~h}$ and incubated under a controlled environment in a climatic chamber as previously described. The time from parasitization to offspring emergence was recorded for each egg mass. The proportion of eggs successfully parasitized was computed as the ratio between the numbers of adult parasitoids emerged and the numbers of eggs exposed. Offspring were sexed upon emergence and the sex ratio (proportion of females) was determined on per egg mass basis. Production of female progeny indicates a sexual compatibility between populations of the different regions.

For each of the variables measured, a one-way analysis of variance was used to compare the different treatments using PROC GLM of SAS SAS, 2001. Where significant $F$ values were obtained and means were separated using the Student-Newman-Keuls' test. Percentages and ratios were arcsine-transformed before analysis, but non-transformed means are presented in the results.

\subsection{Amplification and sequencing of the Wolbachia $16 \mathrm{~S}$ ribosomal RNA partial gene from G. morrilli populations}

The 16S rRNA primers (foward: 5'-TTGTAGCCTGC TATGGTATAACT-3' and reverse: 5'-GAATAGGTATG ATTTTCATGT-3') from O'Neill et al. (1992) were utilized $\left(T_{\mathrm{m}} 52^{\circ} \mathrm{C} ; 1.5 \mathrm{mM} \mathrm{MgCl} ; 40\right.$ cycles $)$ to amplify an $896 \mathrm{bp}$ gene fragment from four clones of an individual from FL. The assigned GenBank Accession Nos. for one of the clones of the 16S rRNA sequence is DQ097266. Since we were only able to detect Wolbachia in the FL population with the standard 1stround PCR reaction, we developed a nested or 2nd-round PCR reaction to increase the sensitivity of detection with primers designed toward the 1st-round 16S rRNA gene (Accession No. DQ097266). One microliter of 1st-round template was utilized $\left(T_{\mathrm{m}} 47^{\circ} \mathrm{C} ; 1.5 \mathrm{mM} \mathrm{MgCl} 2 ; 45\right.$ cycles; $\left.380 \mathrm{bp}\right)$ in 2nd-round PCR reactions with the following primers: WGm-F (forward: 5'-CCTGCTATGGTATAACTTAG-3'; nucleotides 7-20) and WGm-R (reverse: 5'-ACT TCTTCTGTGAGTACC-3'; nucleotides 369-386). Notations for primer names: W, Wolbachia; Gm, G. morrilli. Three clones from one individual from each population (CA, TX, and FL) were analyzed. Assigned GenBank Accession Nos. of the 2nd-round PCR 16S rRNA sequences (380 bp) were: CA, DQ097267-DQ097269; FL, DQ097270-DQ097271; and TX, DQ097272-DQ097273. This primer set (WGm-F/R) was also used to screen whole G. morrilli populations for the presence of Wolbachia.

\section{Results}

\subsection{ISSR-PCR DNA fingerprinting}

Analysis of ISSR-PCR DNA fingerprinting showed that the population of G. morrilli from FL had the same ISSRPCR banding pattern as the population from TX (Fig. 1), whereas the CA population had a banding pattern that differed from TX and FL.

\subsection{Analyses of the COI partial gene in geographic populations}

Sequencing of the COI partial gene produced a $518 \mathrm{bp}$ fragment for all geographic populations and species. A total of 10 haplotypes were identified among the TX/FL and CA populations out of 17 individuals, demonstrating 


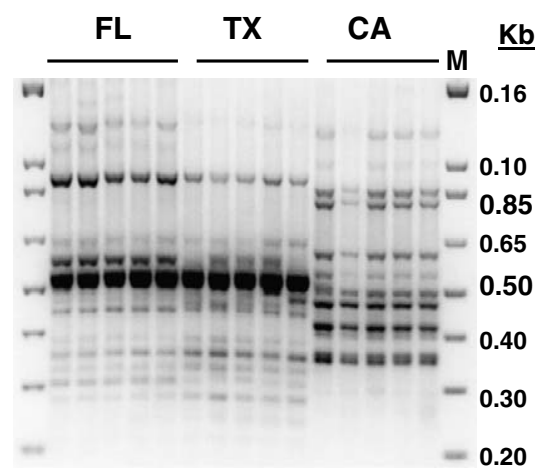

Fig. 1. ISSR-PCR DNA fingerprinting of G. morrilli geographic populations. Five randomly chosen field collected individuals per population from FL, TX, and CA were subjected to ISSR-PCR DNA fingerprinting with a $5^{\prime}$-anchored ISSR primer as described in Section 2. (M) $1.0 \mathrm{~kb}$ Plus DNA Ladder.

genetic variation. Since several individuals per population were analyzed, a pattern of population-specific nucleotides was identified that allowed the discrimination of the different populations. All individuals within the TX and FL (TX/FL) geographic populations contained the same nucleotide, whereas individuals from the CA population contained a different nucleotide (Table 1). For example, at nucleotide \#39 all TX/FL individuals contained an adenine (A), whereas all CA individuals contained a thymine $(\mathrm{T})$. Twenty nucleotide changes or point mutations were identified between the TX/FL and CA populations. Seventeen of these mutations were silent, whereas three led to amino acid substitutions. One transition and 19 transversions were identified between the two populations. Analysis of the G. morrilli morphologically similar South American species from Argentina (ARG), G. annulicornis, showed that this species was very closely related to the G. morrilli populations from CA (Gm-CA). G. annulicornis shared most of the Gm-CAspecific nucleotides.

Levels of genetic divergence in the COI gene among populations were determined by calculating the pairwise estimates for genetic distance. The percentage sequence divergence $(\% \mathrm{D})$ for $\mathrm{COI}$ is shown on Table $2 \mathrm{~A}$. Individuals from TX and FL (TX/FL) were pooled as well as individuals from the CA counties. The intra-populational and specific-variation $(0.0-0.8 \%)$ was small within each population and species. The intra-populational variation for TX/FL and CA was $0.0-0.6$ and $0.0-0.8 \%$, respectively. These results indicate that the TX and FL individuals are genetically similar to each other as are the CA county individuals, corroborating the results in Table 1. In contrast, the $\% \mathrm{D}$ between TX/FL and CA was $5.4-6.5 \%$, overlapping with that of the G. ashmeadi outgroup (6.5-6.9\%). In addition, the results showed that Gm-CA was more closely related to the South American species (G. annulicornis) than it was to G. morrilli from TX/FL (Gm-TX/ FL). The $\% \mathrm{D}$ between TX/FL and G. annulicornis and between CA and G. annulicornis was 4.6-5.2 and 1.0-1.4\%, respectively. A neighbor-joining distance tree showed that the TX/FL and CA populations clustered into two distinctive clades, TX/FL (clade 1) and CA/ARG (clade 2) (Fig. 2). These clades or the topology of the distance tree

Table 1

Mitochondrial COI partial gene DNA sequence from G. morrilli geographic populations: populations-specific nucleotides

\begin{tabular}{|c|c|c|c|c|c|c|c|c|c|c|c|c|c|c|c|c|c|c|c|c|c|}
\hline \multirow[t]{2}{*}{ Individuals } & \multirow[t]{2}{*}{ Haplotype } & \multicolumn{20}{|c|}{ Nucleotide position } \\
\hline & & 39 & 45 & 60 & 100 & 105 & 138 & 141 & 147 & 156 & 168 & 213 & 237 & 330 & 370 & 384 & 390 & 420 & 438 & 441 & 453 \\
\hline WTX2 \#16 & 1 & A & A & $\mathrm{T}$ & A & $\mathrm{T}$ & A & A & A & A & A & A & $\mathrm{T}$ & A & A & $\mathrm{T}$ & A & $\mathrm{T}$ & $\mathrm{T}$ & $\mathrm{T}$ & A \\
\hline WTX3 \#5 & 3 & A & A & $\mathrm{T}$ & A & $\mathrm{T}$ & A & A & A & A & A & A & $\mathrm{T}$ & A & A & $\mathrm{T}$ & A & $\mathrm{T}$ & $\mathrm{T}$ & $\mathrm{T}$ & A \\
\hline WTX3 \#7 & 3 & A & A & $\mathrm{T}$ & A & $\mathrm{T}$ & G & A & A & A & A & A & $\mathrm{T}$ & A & A & $\mathrm{T}$ & A & $\mathrm{T}$ & $\mathrm{T}$ & $\mathrm{T}$ & A \\
\hline WTX3 \#9 & 3 & A & A & $\mathrm{T}$ & A & $\mathrm{T}$ & G & A & A & A & A & A & $\mathrm{T}$ & A & A & $\mathrm{T}$ & A & $\mathrm{T}$ & $\mathrm{T}$ & $\mathrm{T}$ & A \\
\hline FL \#9 & 6 & A & A & $\mathrm{T}$ & A & $\mathrm{T}$ & A & A & A & A & A & A & $\mathrm{T}$ & A & A & $\mathrm{T}$ & A & $\mathrm{T}$ & $\mathrm{T}$ & $\mathrm{T}$ & A \\
\hline FL \#12 & 3 & A & A & $\mathrm{T}$ & A & $\mathrm{T}$ & A & A & A & A & A & A & $\mathrm{T}$ & A & A & $\mathrm{T}$ & A & $\mathrm{T}$ & $\mathrm{T}$ & $\mathrm{T}$ & A \\
\hline OrgCoCA \#8 & 7 & $\mathrm{~T}$ & $\mathrm{~T}$ & A & $\mathrm{T}$ & A & $\mathrm{T}$ & $\mathrm{T}$ & $\mathrm{T}$ & $\mathrm{T}$ & $\mathrm{T}$ & $\mathrm{T}$ & A & $\mathrm{T}$ & $\mathrm{T}$ & A & $\mathrm{T}$ & A & A & A & $\mathrm{T}$ \\
\hline OrgCoCA \#9 & 8 & $\mathrm{~T}$ & $\mathrm{~T}$ & A & $\mathrm{T}$ & A & $\mathrm{T}$ & $\mathrm{T}$ & $\mathrm{T}$ & $\mathrm{T}$ & $\mathrm{T}$ & $\mathrm{T}$ & A & $\mathrm{T}$ & $\mathrm{T}$ & A & $\mathrm{T}$ & A & A & A & $\mathrm{T}$ \\
\hline OrgCoCA \#16 & 8 & $\mathrm{~T}$ & $\mathrm{~T}$ & A & $\mathrm{T}$ & A & $\mathrm{T}$ & $\mathrm{T}$ & $\mathrm{T}$ & $\mathrm{T}$ & $\mathrm{T}$ & $\mathrm{T}$ & A & $\mathrm{T}$ & $\mathrm{T}$ & A & $\mathrm{T}$ & A & A & A & $\mathrm{T}$ \\
\hline OrgCoCA \#22 & 8 & $\mathrm{~T}$ & $\mathrm{~T}$ & A & $\mathrm{T}$ & A & $\mathrm{T}$ & $\mathrm{T}$ & $\mathrm{T}$ & $\mathrm{T}$ & $\mathrm{T}$ & $\mathrm{T}$ & A & $\mathrm{T}$ & $\mathrm{T}$ & A & $\mathrm{T}$ & A & A & A & $\mathrm{T}$ \\
\hline SMCA \#34 & 8 & $\mathrm{~T}$ & $\mathrm{~T}$ & A & $\mathrm{T}$ & A & $\mathrm{T}$ & $\mathrm{T}$ & $\mathrm{T}$ & $\mathrm{T}$ & $\mathrm{T}$ & $\mathrm{T}$ & A & $\mathrm{T}$ & $\mathrm{T}$ & A & $\mathrm{T}$ & A & A & A & $\mathrm{T}$ \\
\hline G. ann \#3 & 11 & $\mathrm{~T}$ & $\mathrm{~T}$ & A & $\mathrm{T}$ & A & $\mathrm{T}$ & $\mathrm{T}$ & $\mathrm{T}$ & $\mathrm{T}$ & $\mathrm{T}$ & $\mathrm{T}$ & A & $\mathrm{T}$ & $\mathrm{T}$ & A & $\mathrm{T}$ & A & A & A & $\mathrm{T}$ \\
\hline G. ann \#4 & 12 & $\mathrm{~T}$ & $\mathrm{~T}$ & A & $\mathrm{T}$ & A & $\mathrm{T}$ & $\mathrm{T}$ & $\mathrm{T}$ & $\mathrm{T}$ & $\mathrm{T}$ & $\mathrm{T}$ & A & $\mathrm{T}$ & $\mathrm{T}$ & A & $\mathrm{T}$ & A & A & A & $\mathrm{T}$ \\
\hline G. ann \#5 & 13 & $\mathrm{~T}$ & $\mathrm{~T}$ & A & $\mathrm{T}$ & A & $\mathrm{T}$ & $\mathrm{T}$ & $\mathrm{T}$ & $\mathrm{T}$ & $\mathrm{T}$ & $\mathrm{T}$ & A & $\mathrm{T}$ & $\mathrm{T}$ & A & $\mathrm{T}$ & A & A & A & $\mathrm{T}$ \\
\hline
\end{tabular}

Sequences were aligned with the ClustalV program of DNAStar. WTX2 and 3, two populations from Weslaco, Texas (Hidalgo county); FL, Quincy, Florida; OrgCoCA, Orange county, California; SMCA, San Marcos, California (San Diego county); G. ann, G. annulicornis (near G. morrilli from Argentina). The numbers (\#) following the population abbreviation are randomly chosen individuals. 
Table 2

Pairwise DNA sequence distances (range) of genes or gene fragments from geographic populations of G. morrilli showing percentage divergence

\begin{tabular}{lllll}
\hline Pop. & TX/FL & CA & G. ann & G. ash \\
\hline A & & & & \\
TX/FL & $0.0-0.6$ & & & \\
CA & $5.4-6.5$ & $0.0-0.8$ & & \\
G. ann & $4.6-5.2$ & $1.0-1.4$ & $0.2-0.4$ & \\
G. ash & $6.5-6.9$ & $6.7-7.5$ & $7.1-7.5$ & $0.0-0.2$ \\
B & & & & \\
$\quad$ TX/FL & $0.00-5.10$ & & & \\
CA & $7.60-11.0$ & $0.00-0.50$ & & \\
G. ann & $7.10-9.50$ & $1.90-2.50$ & $0.00-0.30$ & \\
G. ash & $7.30-10.6$ & $7.10-8.10$ & $6.60-6.90$ & $0.0-0.20$ \\
C & & & & \\
TX/FL & $0.0-0.9$ & & & \\
CA & $5.5-6.9$ & $0.0-0.6$ & & \\
G. ann & $5.7-6.6$ & $1.8-2.3$ & $0.0-0.1$ & \\
G. ash & $6.6-7.8$ & $5.6-6.3$ & $5.6-6.3$ & $0.3-0.6$ \\
\hline
\end{tabular}

(A) COI, (B) COII, and (C) ITS2. The alignment program ClustalV from DNAStar was utilized for these analyses. To account for intra- and inter-populational variation, several individuals (3-5) were included per population. TX/FL, Texas and Florida (individuals were pooled); CA, California, individuals from Orange and San Diego, Co.; G. ann, G. annulicornis (near G. morrilli from Argentina); G. ash, G. ashmeadi (outgroup). For the number of individuals analyzed per population, refer to Figs. 2-4 for COI, COII, and ITS2, respectively.

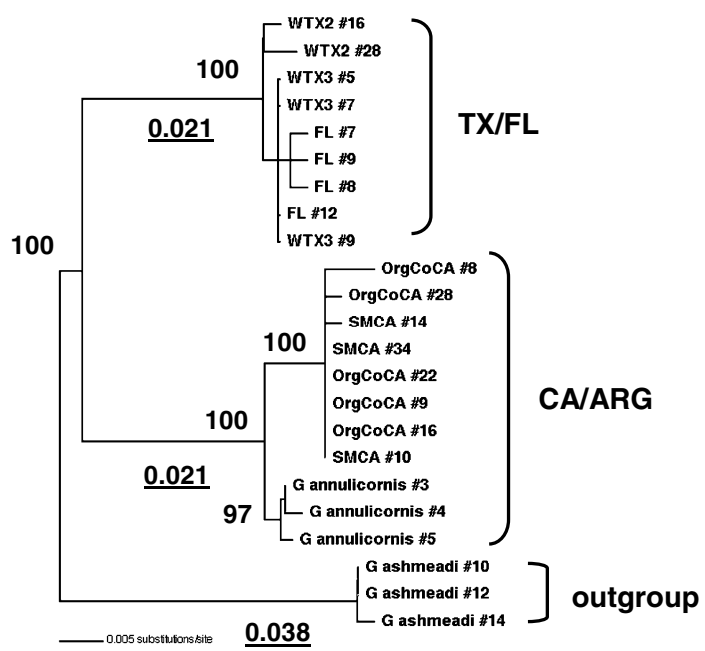

Fig. 2. Dendrogram of the mitochondrial COI partial gene from geographic populations of G. morrilli. The neighbor-joining tree was created with the phylogenetic program PAUP $4.0 \mathrm{~b} 10$ (Swofford, 2002). In the genetic distance tree G. ashmeadi are included as an outgroup. For comparison purposes the egg parasitoids from Argentina (G. annulicornis) morphologically similar to G. morrilli were included. The tree displays branch lengths (below branches) and bootstrap values (above branches) as a percentage of 1000 replications. To account for intra- and inter-populational variation, several randomly chosen field collected individuals were included. SMCA, San Marcos, CA; OrgCoCA; Orange county, CA; WTX2, 3, two populations from Weslaco, TX; FL, Quincy, FL.

were supported by high bootstrap values $(100 \%)$. The distance tree showed that G. annulicornis was clustered within clade 2 (CA/ARG), again showing their close genetic relationship.

\subsection{Analyses of the COII partial gene in geographic populations}

Sequencing of the partial COII gene produced different sized fragments for the various geographic populations and species. COII size fragments of 651,649 , and $650 \mathrm{bp}$ were generated for the TX/FL, CA and G. annulicornis, and G. ashmeadi populations, respectively. Extensive haplotype variation was observed in the TX/FL populations with eight haplotypes (\#1-8) out of eight individuals. The identification of population-specific nucleotides for the COII gene is shown in Table 3. Thirty-three nucleotide substitutions were observed between the TX/FL and CA geographic populations. Eighteen substitutions were silent mutations, 13 were missense mutations that led to 13 amino acid substitutions, and two were base-pair deletions (AT). Different start codons are utilized by the two different proteins, therefore both are functional. Eight transitions and 23 transversions were observed between the TX/FL and CA populations. G. annulicornis shared most of the GmCA-specific nucleotides.

Levels of genetic divergence in the COII gene among populations are shown in Table 2B. In general, the intrapopulational variation within geographic populations and species was small $(0.00-0.5 \% \mathrm{D})$, with the exception of the TX populations $(3.60-5.10 \% \mathrm{sD})$. The $\% \mathrm{D}$ between the TX and FL populations was $0.0-5.1 \%$, which falls within the range of the intra-populational variation of these two populations, indicating their genetic similarity. In contrast, the $\% \mathrm{D}$ between $\mathrm{TX} / \mathrm{FL}$ and CA was $7.60-11.0 \%$, falling within the range $(7.30-10.6 \%)$ of the outgroup (G. ashmeadi). A neighbor-joining distance tree demonstrated that the TX/ FL and CA populations clustered into two distinctive clades (TX/FL and CA/ARG), supported by high bootstrap values (100\%) (Fig. 3). G. annulicornis clustered within the CA/ARG clade. The haplotype of individual OrgCoCA \#16, clustered with the G. annulicornis cluster, demonstrating an example of ancestral shared polymorphism (Simon et al., 1994).

\subsection{Analyses of ITS2 rDNA fragments in geographic populations}

Sequencing of ITS2 rDNA fragments generated eight variants (combining size and base-pair differences) in the TX/FL populations. The size of the variants ranged from 1063 to $1067 \mathrm{bp}$ in the 11 individuals sequenced, therefore demonstrating the need to include several individuals per population to account for intra- and inter-populational variation. This type of natural variation is expected for ITS regions. Interestingly, the CA populations were found to have a different sized ITS2 region ranging in size from 851 to $853 \mathrm{bp}$; a difference of 211-212 to 214-215 bp between the TX/FL and CA populations. The G. annulicornis population also had an ITS2 region fragment of similar size (850-854bp) to Gm-CA.

Levels of genetic divergence in the ITS2 rDNA fragment among populations are shown in Table $2 \mathrm{C}$. The 
Table 3

Mitochondrial COII partial gene DNA sequence from $G$. morrilli geographic populations: population-specific nucleotides

Individuals Haplotype Nucleotide position

49506783106109125173183191200203218223230238272274294352353355359385424434451473517547550577583

\begin{tabular}{|c|c|c|c|c|c|c|c|c|c|c|c|c|c|c|c|c|c|c|c|c|c|c|c|c|c|c|c|c|c|c|c|}
\hline WTX2 \#14 & 1 & $\mathrm{~A} T \mathrm{~A}$ & G A & A & G & $\mathrm{T}$ & A & $\mathrm{T}$ & $\mathrm{T}$ & $\mathrm{T}$ & A & $\mathrm{T}$ & $\mathrm{T}$ & A & A & $\mathrm{T}$ & $\mathrm{C}$ & A & G & A & A & A & A & A & $\mathrm{T}$ & A & $\mathrm{T}$ & A & $\mathrm{T}$ & $\mathrm{T}$ & $\mathrm{T}$ \\
\hline WTX2 \#18 & 2 & $\mathrm{TA}$ & G A & A & $\mathrm{G}$ & $\mathrm{T}$ & & $\mathrm{T}$ & $\mathrm{T}$ & $\mathrm{T}$ & A & $\mathrm{T}$ & $\mathrm{T}$ & A & A & $\mathrm{T}$ & $\mathrm{C}$ & A & G & A & A & A & A & A & $\mathrm{T}$ & A & $\mathrm{T}$ & & $\mathrm{T}$ & $\mathrm{C}$ & $\mathrm{T}$ \\
\hline WT & 4 & $\mathrm{TA}$ & $\mathrm{GA}$ & A & G & $\mathrm{T}$ & A & $\mathrm{T}$ & $\mathrm{T}$ & $\mathrm{T}$ & A & $\mathrm{T}$ & $\mathrm{T}$ & A & A & $\mathrm{T}$ & $\mathrm{C}$ & A & G & A & A & A & A & A & $\mathrm{T}$ & A & $\mathrm{T}$ & 4 & $\mathrm{~T}$ & $\mathrm{~T}$ & $\mathrm{~T}$ \\
\hline L \#12 & 6 & $\mathrm{~T} \mathrm{~A}$ & G A & A & G & $\mathrm{T}$ & A & $\mathrm{T}$ & $\mathrm{T}$ & $\mathrm{T}$ & A & $\mathrm{T}$ & $\mathrm{T}$ & A & A & $\mathrm{T}$ & $\mathrm{C}$ & A & G & A & A & $\Delta$ & A & A & $\mathrm{T}$ & A & $\mathrm{T}$ & A & $\mathrm{T}$ & $\mathrm{T}$ & $\mathrm{T}$ \\
\hline $\mathrm{FL}$ & 7 & $\mathrm{TA}$ & G A & A & $\mathrm{G}$ & $\mathrm{T}$ & A & $\mathrm{T}$ & $\mathrm{T}$ & $\mathrm{T}$ & A & $\mathrm{T}$ & $\mathrm{T}$ & A & A & $\mathrm{T}$ & $\mathrm{C}$ & A & G & A & A & A & A & A & $\mathrm{T}$ & A & $\mathrm{T}$ & A & $\mathrm{T}$ & $\mathrm{T}$ & $\mathrm{T}$ \\
\hline FL \#14 & 8 & $\mathrm{TA}$ & G A & A & G & $\mathrm{T}$ & A & $\mathrm{T}$ & $\mathrm{T}$ & $\mathrm{T}$ & A & $\mathrm{T}$ & $\mathrm{T}$ & A & A & $\mathrm{T}$ & $\mathrm{C}$ & A & G & A & A & A & A & A & $\mathrm{T}$ & A & $\mathrm{T}$ & A & $\mathrm{T}$ & $\mathrm{T}$ & $\mathrm{T}$ \\
\hline $\mathrm{rg}$ & 10 & $--\mathrm{T}$ & A $\mathrm{T}$ & $\mathrm{T}$ & A & A & $\mathrm{T}$ & A & A & A & G & A & A & $\mathrm{T}$ & G & A & $\mathrm{T}$ & $\mathrm{T}$ & A & $\mathrm{T}$ & G & $\mathrm{T}$ & $\mathrm{T}$ & G & A & $\mathrm{T}$ & A & $\mathrm{T}$ & A & A & A \\
\hline Org & 9 & $--\mathrm{T}$ & A $T$ & $\mathrm{~T}$ & A & A & $\mathrm{T}$ & A & A & A & G & A & A & $\mathrm{T}$ & G & A & $\mathrm{T}$ & $\mathrm{T}$ & A & $\mathrm{T}$ & G & $\mathrm{T}$ & $\mathrm{T}$ & $\mathrm{G}$ & A & $\mathrm{T}$ & A & $\mathrm{T}$ & A & A & A \\
\hline OrgC & & $--\mathrm{T}$ & A T & $\mathrm{T}$ & A & A & $\mathrm{T}$ & A & A & A & G & A & A & $\mathrm{T}$ & G & A & $\mathrm{T}$ & $\mathrm{T}$ & A & $\mathrm{T}$ & $\mathrm{G}$ & $\mathrm{T}$ & $\mathrm{T}$ & $\mathrm{G}$ & A & $\mathrm{T}$ & A & $\mathrm{T}$ & A & A & A \\
\hline OrgCoCA & & $--\mathrm{T}$ & A $T$ & $\mathrm{~T}$ & A & A & $\mathrm{T}$ & A & A & A & G & A & A & $\mathrm{T}$ & G & A & $\mathrm{T}$ & $\mathrm{T}$ & A & $\mathrm{T}$ & G & $\mathrm{T}$ & $\mathrm{T}$ & G & A & $\mathrm{T}$ & A & $\mathrm{T}$ & A & A & A \\
\hline $1+7$ & 13 & $-\mathrm{T}$ & A $T$ & $\mathrm{~T}$ & A & A & $T$ & A & A & A & G & 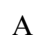 & A & $\mathrm{T}$ & G & A & $\mathrm{T}$ & $\mathrm{T}$ & A & $\mathrm{T}$ & G & $\mathrm{T}$ & $\mathrm{T}$ & G & A & $\mathrm{T}$ & $\mathrm{A}$ & $\mathrm{T}$ & A & A & A \\
\hline M & 9 & $--\mathrm{T}$ & A $T$ & $\mathrm{~T}$ & A & A & $\mathrm{T}$ & A & A & A & G & A & A & $\mathrm{T}$ & G & A & $\mathrm{T}$ & $\mathrm{T}$ & A & $\mathrm{T}$ & G & $\mathrm{T}$ & $\mathrm{T}$ & $\mathrm{G}$ & A & $\mathrm{T}$ & A & $\mathrm{T}$ & A & A & A \\
\hline & 14 & $-\mathrm{T}$ & A $\mathrm{T}$ & $\mathrm{T}$ & A & A & $\mathrm{T}$ & A & A & A & G & A & A & $\mathrm{T}$ & G & A & 2 & $\mathrm{~T}$ & A & & $\mathrm{G}$ & 1 & $\mathrm{~T}$ & G & A & $\mathrm{T}$ & A & & & & A \\
\hline G. ann \#20 & 16 & $-\mathrm{T}$ & A T & $\mathrm{T}$ & A & A & $\mathrm{T}$ & A & A & A & G & A & A & $\mathrm{T}$ & G & A & $\mathrm{T}$ & $\mathrm{T}$ & A & $\mathrm{T}$ & G & $\mathrm{T}$ & $\mathrm{T}$ & G & A & $\mathrm{T}$ & A & $\mathrm{T}$ & A & A & A \\
\hline
\end{tabular}

Sequences were aligned with the ClustalV program of DNAStar. WTX2 and 3, two populations from Weslaco, Texas (Hidalgo county); FL, Quincy, Florida; OrgCoCA, Orange county, California; SMCA, San Marcos, California (San Diego county); G. ann, G. annulicornis (near G. morrilli from Argentina). The numbers (\#) following the population abbreviation are randomly chosen individuals.

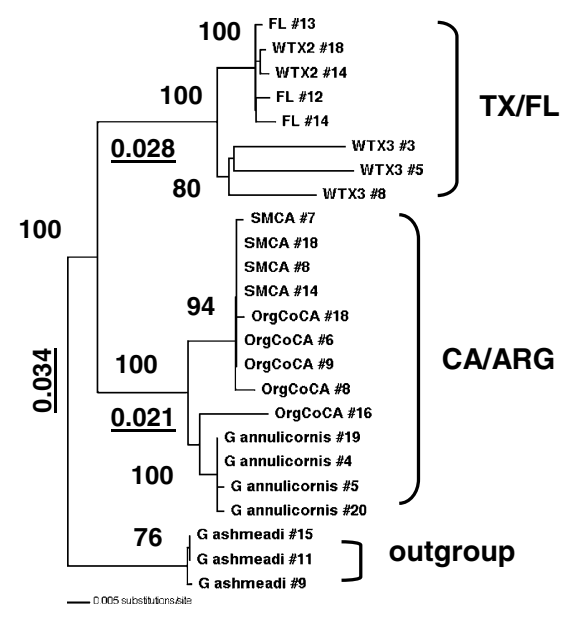

Fig. 3. Dendrogram of the mitochondrial COII partial gene from geographic populations of G. morrilli. In the genetic distance tree G. ashmeadi are included as an outgroup. The tree displays branch lengths (below branches) and bootstrap values (above branches) as a percentage of 1000 replications. To account for intra- and inter-populational variation, several randomly chosen field collected individuals (3-5) were included. SMCA, San Marcos, CA; OrgCoCA; Orange county, CA; WTX2, 3, two populations from Weslaco, TX; FL, Quincy, FL.

intra-populational and specific-variation among the geographic populations and species was small $(0.0-0.9 \% \mathrm{D})$. The $\% \mathrm{D}$ between TX and FL was $0.0-0.9 \%$, falling within the intra-populational range of both populations and therefore shows that they are closely related. In contrast, the $\% \mathrm{D}$ between the TX/FL and CA populations was
$5.5-6.9 \%$, falling within the range $(6.6-7.8 \%)$ of the outgroup ( $G$. ashmeadi). The $G$. annulicornis population from Argentina was more closely related to Gm-CA showing a $\% \mathrm{D}$ of $1.8-2.3$ as compared to Gm-TX/FL $(5.7-6.6 \%)$. The neighbor-joining distance tree in Fig. 4 demonstrated that the TX/FL and CA populations

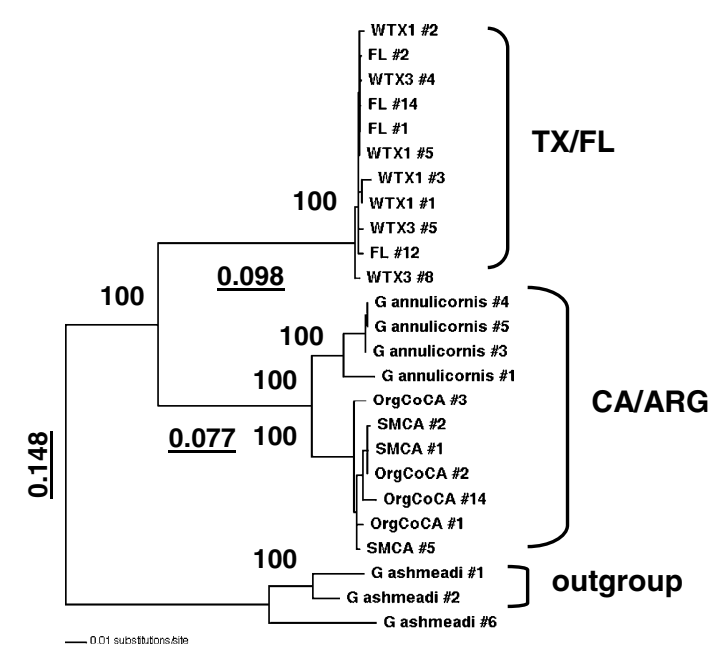

Fig. 4. Dendrogram of the ITS2 rDNA fragment from geographic populations of G. morrilli. In the neighbor-joining genetic distance tree G. ashmeadi are included as an outgroup. The tree displays branch lengths (below branches) and bootstrap values (above branches) as a percentage of 1000 replications. To account for intra- and inter-populational variation, several randomly chosen field collected individuals (3-7) were included. SMCA, San Marcos, CA; OrgCoCA; Orange county, CA; WTX1, 3, two populations from Weslaco, TX; FL, Quincy, FL. 
clustered into two distinctive clades supported by high bootstrap values $(100 \%)$. G. annulicornis clustered within the CA/ARG clade.

\subsection{Reproductive compatibility studies}

Mated G. morrilli females from the various crosses successfully parasitized eggs of the GWSS, but the percentages varied significantly with treatment $(F=12.54, d f=5$, $82, P<0.0001)$. Nearly all GWSS eggs exposed were successfully parasitized in all the direct and reciprocal crosses, except for the $\$ \mathrm{TX} \times{ }_{0}^{\lambda} \mathrm{CA}$ treatment for which
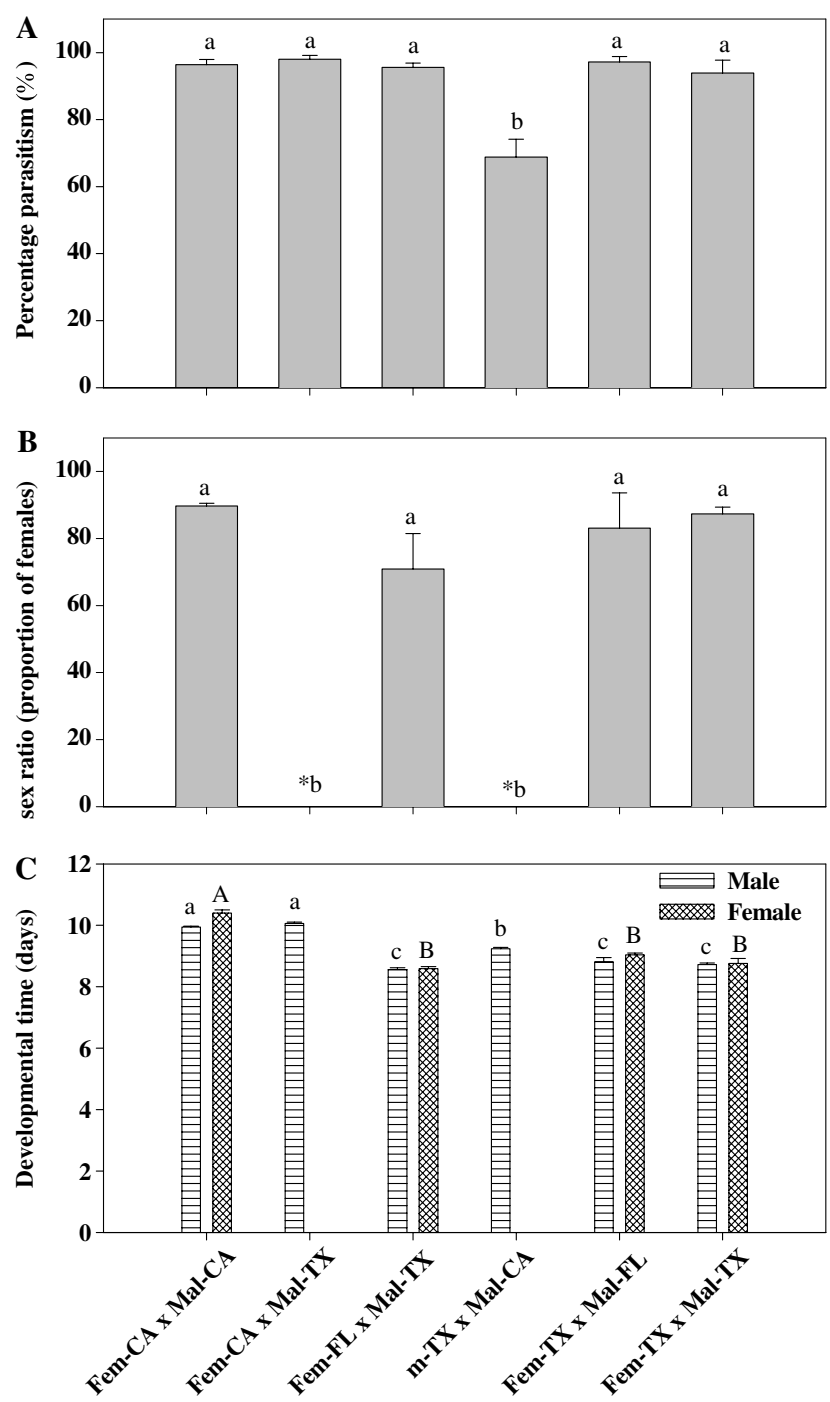

Fig. 5. (A) Mean percentage of eggs successfully parasitized by G. morrilli females obtained from different crosses. Error bars indicate standard error of the mean (SEM). Means followed by the same letter are not significantly different using the SNK test. (B) Mean percentage of female offspring when GWSS eggs were parasitized by G. morrilli females obtained from different crosses. Error bars indicate SEM. Means followed by the same letter are not significantly different using the SNK test. ${ }^{*}$ Sex ratio $=0.0$. (C) Mean immature developmental time of G. morrilli in GWSS host eggs parasitized by females obtained from different crosses Error bars indicate SEM. Means followed by the same letter are not significantly different using the SNK test. only $65 \%$ of eggs were successfully parasitized (Fig. 5A). The crosses $+\mathrm{CA} \times{ }^{\top} \mathrm{CA}$ and $+\mathrm{CA} \times{ }^{\mathrm{T}} \mathrm{TX}$ yielded the longest immature developmental period for males; the lowest periods were obtained for immatures from $\mathrm{PFL} \times{ }^{\mathrm{T}} \mathrm{TX}$, ${ }_{q} \mathrm{TX} \times{ }^{\top} \mathrm{FL}$, and $\$ \mathrm{TX} \times{ }^{\top} \mathrm{TX}$. Percentage of females produced varied significantly with treatment $(F=115.05$, $d f=5,82, P<0.0001)$. The sex ratios of $G$. morrilli progeny produced from the homogamic $\left(+\mathrm{CA} \times{ }^{\top} \mathrm{CA}\right.$ and $\left.\$ \mathrm{TX} \times \delta^{\top} \mathrm{TX}\right)$ and the heterogamic $\left(+\mathrm{TX} \times \jmath^{\lambda} \mathrm{FL}\right.$ and $\left.\$ \mathrm{FL} \times{ }^{\mathrm{T}} \mathrm{TX}\right)$ crosses were female-biased and similar with $>70 \%$ of female offsprings (Fig $5 \mathrm{~B}$ ). In contrast, the heterogamic cross $\odot \mathrm{CA} \times{ }^{\top} \mathrm{TX}$ and its reciprocal cross TXX $\times{ }^{\top} \mathrm{CA}$ did not produce any female progeny. Relative to their $+\mathrm{TX} \times{ }^{\mathrm{T}} \mathrm{TX}$ homogamic cross, the relative compatibility indices (ratio between the proportion of females in heterogamic and homogamic cross) of $\$ \mathrm{TX} \times{ }^{\lambda} \mathrm{CA}$ and $\odot \mathrm{TX} \times{ }^{\top} \mathrm{FL}$ were 0.0 and 0.95 , respectively. Similarly, the relative compatibility index of the +CA $\times$ o TX was 0.0. The immature developmental time of G. morrilli within eggs of GWSS significantly varied with treatment $(F=212.04, d f=5,1018, P<0.0001)$ but not with $\operatorname{sex}(F=0.08, d f=1,1018, P=0.78)$. For females, the longest immature developmental time was recorded for $+\mathrm{CA} \times{ }_{0} \mathrm{CA}$, whereas no significant differences were recorded for the three crosses $\$ \mathrm{FL} \times{ }^{\hat{\top}} \mathrm{TX}, \propto \mathrm{TX} \times{ }^{\hat{\lambda}} \mathrm{FL}$, and $\odot \mathrm{TX} \times{ }_{0} \mathrm{TX}$ (Fig. 5C).

\subsection{Analyses of the Wolbachia $16 S r R N A$ partial gene from geographic populations of $G$. morrilli}

To determine whether the different geographic populations of G. morrilli were infected with Wolbachia, the 16S rRNA partial gene was analyzed. Initially four clones were sequenced from one individual G. morrilli from FL. The four clones showed a $\% \mathrm{D}$ range of $0.0-0.1$. A BLAST analysis (Altschul et al., 1997) of this 16S rRNA sequence showed a $99 \%$ similarity to the Wolbachia pipientis sequence (originally identified from the mosquito Culex pipiens) (Barr, 1980; O’Neill et al., 1992; Werren et al., 1995) detected in the GWSS by Moran et al. (2003), Genbank Accession Nos. AF501664. This Wolbachia strain belongs to the B-group subdivision. For the 16S rRNA 2nd-round PCR reactions, three individuals per population (CA, FL, and TX) were amplified and sequenced. Out of the nine sequences ( $380 \mathrm{bp}$ ) or clones, seven variants were identified varying at most by three nucleotides, showing a \%D range of $0.0-0.8$. One variant (GenBank Accession No. DQ097269) was shared among the three populations. Since two rounds of amplification were performed, it was possible that some of these nucleotide differences among the sequences could be due to Taq DNA polymerase errors. Screening for Wolbachia with our 2nd-round PCR assay of the geographic populations of G. morrilli resulted in positive detection as follows: CA, 30 of $34(88 \%)$; FL, 18 of $20(90 \%)$; and TX, 30 of 32 $(94 \%)$. Males and females were found infected with Wolbachia in equal portions within populations. 


\section{Discussion}

The current report represents the first combined genetic and hybridization study to confirm that the population of G. morrilli from California is a new species (sp. n). This is confirmed by morphological analyses (S. Triapitsyn, personal communication). A phylogenetic approach was implemented by sequencing standard genes or gene fragments (COI, COII, and ITS2) useful in identification and discrimination of closely related species (Avise, 2000; Roderick, 2004; Rosen, 1977). The internal transcribed spacer regions (ITS) have also been used extensively in the examination of the taxonomic status of species and for diagnostic purposes (reviewed in Collins and Paskewitz, 1996). Recently (de León et al., 2004b; de León and Jones, 2005) and in the current report, we observed a powerful correlation in DNA banding patterns and distinct species with the ISSR-PCR DNA fingerprinting method with Mymaridae egg parasitoids. The method has been used to distinguish about eight Gonatocerus egg parasitoid species (de León, 2005). In the present study, based on ISSR-PCR banding patterns, we were able to predict the species status of the G. morrilli population from FL. The results demonstrated populations from FL and TX as distinct from the CA populations. ISSR-PCR was also able to distinguish the South American egg parasitoid species, G. annulicornis (data not shown). Even though ISSR-PCR markers are scored as dominant, the ISSR-PCR technique using 5 '-anchored or compound ISSR primers is still a very sensitive and useful technique because it targets random SSR or microsatellites (de León and Jones, 2004; Zietkiewicz et al., 1994). An additional advantage is that the same ISSR primer can be rapidly applied across several different species (e.g., insects, plants, fungi, and bacteria) without prior knowledge of DNA sequences (de León, unpublished data), a capability not found with microsatellites. Banding patterns are consistent because the anchors serve to fix the annealing of the primer to a single position of the target site, thus resulting in a low level of slippage during amplification (Zietkiewicz et al., 1994; reviewed in Karp and Edwards, 1997). Using ISSR-PCR with compound ISSR primers, de León et al. (2003, 2004a) determined the population structure and the origin (TX) of the GWSS that invaded CA. In addition, ISSR-PCR identified genetic differentiation among geographic populations of another GWSS egg parasitoid, G. ashmeadi (de León and Jones, 2005) that sequence data (COI and ITS2) could not detect (de León, unpublished data).

Sequence data from the mitochondrial COI and COII partial genes and the ITS2 rDNA fragment indicate that the studied populations of G. morrilli contain two distinct evolutionary groups. Populations from TX and FL formed one well-supported clade, while populations from CA formed another well-supported clade. Variation between the two clades with all three genes was greater between clades than within them. The $\% \mathrm{D}$ between the TX/FL and CA populations fell within the range of the outgroup
(G. ashmeadi). Size differences were also seen within the COII gene and the ITS2 rDNA fragment between the geographic populations. For COII, the amplification product sizes were 651 and $649 \mathrm{bp}$, respectively, for the TX/FL and CA populations. A difference of 213-215 bp was identified between the geographic populations: $1063-1067 \mathrm{bp}$ for TX/ FL and 851-853 bp for CA. Interestingly, the South American egg parasitoid species (G. annulicornis) was found to be closely related to the CA populations. This relationship was demonstrated by all three genes analyzed and as seen on Tables 1 and 3; G. annulicornis shared most of the population-specific nucleotides with the populations from CA. In addition, the COII genes and the ITS2 rDNA fragments were of similar size between the populations from CA and G. annulicornis. Sequence data from three independent gene regions are concordant and indicate a deep divergence between the geographic populations (TX/FL and CA). The divergence between these populations indicates that the populations from CA and Gm-TX/FL diverged for some time longer than the populations from CA and G. annulicornis.

Reproductive compatibility studies further support the existence of a new species (sp. n.) as found by the molecular analyses. The high egg parasitism rates obtained in the present study showed that G. morrilli females of the three origins efficiently utilized GWSS eggs as hosts. Despite this high efficiency in parasitizing eggs of the GWSS, immature developmental time was longest for G. morrilli females originating from CA. This immature developmental time for G. morrilli from CA may be due to the fact that its primary host is likely H. liturata and not GWSS, whereas G. morrilli from FL and TX have coevolved with the GWSS. Although adult males emerged before females in all the crosses producing both sexes, no significant differences were detected between the immature developmental time of males and females. The proportions of female progeny in the heterogamic crosses of $+\mathrm{FL} \times{ }^{\top} \mathrm{TX}$ and $\odot \mathrm{TX} \times{ }^{\lambda} \mathrm{FL}$ were similar to the homogamic cross of $\mathrm{TX} \times{ }^{1} \mathrm{TX}$, suggesting that these crosses are completely compatible. In contrast, the heterogamic crosses

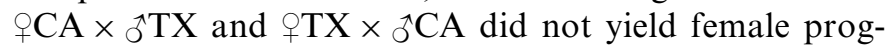
eny and their relative compatibility indices were 0.0 , indicating that G. morrilli from CA and TX are completely reproductively incompatible and therefore reproductively isolated (Pinto et al., 1991).

Initially, $W$. pipientis was only detected in the FL population, but the development of the nested or 2nd-round PCR assay significantly increased the detection efficiency of Wolbachia. The bacterium was detected in the G. morrilli populations with a detection efficiency of $88 \%$ or better, with males and females infected at equal portions. Development of the 2nd-round PCR assay for the $16 \mathrm{~S}$ rRNA gene should help improve detection of Wolbachia in other arthropods. At present, PCR surveys have shown that over $16 \%$ of insect species tested carry Wolbachia (Werren and Windsor, 2000). Another study using long PCR showed that the number of arthropods infected with 
Wolbachia could reach 70\% (Jeyaprakash and Hoy, 2000).

Wolbachia-induced cytoplasmic incompatibility (CI) can occur in two ways: (1) an infected male mating with an uninfected female (unidirectional) and (2) male and female harboring different strains of Wolbachia (bidirectional) (Werren, 1997). In the present study, unidirectional CI can be ruled out since both males and females were infected with Wolbachia in equal portions. However, at this point bidirectional CI remains to be ruled out since $16 \mathrm{~S}$ rDNA is a very conserved gene and therefore can not accurately determine whether the different wasps populations actually harbor the same strain of Wolbachia. The only way to determine bidirectional CI is by antibiotic curing.

The present results, coupled with those of the molecular analyses and our previous work demonstrating that these populations shared no ISSR-PCR bands (de León et al., 2004b), and the taxonomic work by S. Triapitsyn (personal communication) unambiguously demonstrate that the G. morrilli population from CA is a new species (sp. n). As mentioned in the Materials and methods, the new species name will be released upon S. Triapitsyn's publication. Because G. morrilli females from each of the geographic origins mated with males of any origin in the laboratory, it is possible that mating will also occur if these individuals were present together in a given environment. However, heterogamic crosses between individuals from TX and CA will produce only males, thus negatively impacting the biological control of GWSS. Because $G$. morrilli from TX have coevolved with the GWSS, it is crucial to use parasitoids of this origin in the classical biological control program of the GWSS in CA. The fact that the GWSS originated from TX has recently been confirmed by Smith (2005) by phylogenetic analysis of the COI gene. The USDA, ARS (Weslaco) has sent the CDFA the G. morrilli TX species to CA to restart this biological control program. The molecular diagnostic markers developed from our previous (de León et al., 2004b) and current studies are already in use to help monitor the establishment of G. morrilli in the biological control program in CA (de León and Morgan, 2005).

\section{Acknowledgments}

We thank Marissa González, Lisa A. Ledezma, and Rosa I. Ruiz for their excellent technical assistance. We also thank William Warfield, USDA, ARS (Weslaco, TX) and Christopher Tipping and Russell Mizell III from the University of Florida, Quincy, FL for providing G. morrilli. We are grateful to Eduardo Virla, CONICET-PROMIMI (Argentina) and Guillermo Logarzo from USDA, ARS, SABCL (Argentina) for collection of G. annulicornis from Argentina. We thank Serguei Triapitsyn from the University of California, Riverside for crucial and useful taxonomic discussions of GWSS egg parasitoids. We thank Marilyn Casas, USDA, ARS (Weslaco, TX) for rearing G. annulicornis. We thank Nina M. Bárcenas, WSD/USDA, ARS, YARL (Wapato, WA) and Richard L. Roehrdanz, ARS Fargo, ND for reading and improving a previous version of the manuscript. Lastly, we thank the anonymous reviewers and editor for improving the manuscript.

\section{References}

Altschul, S.F., Madden, T.L., Schäffer, A.A., Zhang, J., Zhang, Z., Miller, W., Lipman, D.J., 1997. Gapped BLAST and PSI-BLAST: a new generation of protein database search programs. Nucleic Acids Res. 25, 3389-3402.

Avise, J.C., 2000. Phylogeography: The History and Formation of Species. Harvard University Press, Cambridge, MA.

Barr, A.R., 1980. Cytoplasmic incompatibility in natural populations of a mosquito, Culex pipiens. Nature 283, 71-72.

Breeuwer, J.A.J., Werren, J.H., 1990. Microorganisms associated with chromosome destruction and reproductive isolation. Nature 346, 558-560.

Brlansky, R.H., Timmer, L.W., French, W.J., McCoy, R.E., 1983. Colonization of the sharpshooter vectors, Oncometopia nigricans and Homalodisca coagulata, by xylem-limited bacteria carriers of xylem-limited bacterial disease. Phytopathology 73, 530-535.

Brown, J.K., 2004. Tracing the origin of cryptic insect pests and vectors, and their natural enemies. In: Ehler, L.E., Sforza, R., Mateille, T. (Eds.), Genetics, Evolution, and Biological Control. CABA International, Wallingford, UK, pp. 113-132.

Bursk, R.A., Redak, R.A., 2003. The identity and reinstatement of Homalodisca liturata Ball and Phera lacerta Fowler (Hemiptera: Cicadellidae). P. Entomol. Soc.Wash. 105, 674-678.

CDFA, 2003. Pierce's disease program report to the legislature. California Department of Food and Agriculture.

Collins, F.H., Paskewitz, S.M., 1996. A review of the use of ribosomal DNA (rDNA) to differentiate among cryptic Anopheles species. Insect Mol. Biol. 5, 1-9.

de León, J.H., 2005. The utility of inter-simple sequence repeat-polymerase chain reaction (ISSR-PCR) to distinguish geographic populations of the smoke-tree sharpshooter Homalodisca liturata and egg parasitoids of the genus Gonatocerus. In: Tariq, M.A., Blincoe, P., Mochel, M., Oswalt, S., Esser, T. (Eds.), (Organized by the California Department of Food and Agriculture), Proceedings of the Pierce's Disease Research Symposium, December 5-7, 2005, San Diego Mariott Hotel and Marina, San Diego, CA. Copeland Printing, Sacramento California, pp. 298-301.

de León, J.H., Jones, W.A., 2004. Detection of DNA polymorphisms in Homalodisca coagulata (Homoptera: Cicadellidae) by polymerase chain reaction-based DNA fingerprinting methods. Ann. Entomol. Soc. Am. 97, 574-585.

de León, J.H., Morgan, D.J.W., 2005. Small scale post-release evaluation of a Gonatocerus morrilli program in California against the glassy-winged sharpshooter: utility of developed molecular diagnostic tools. In: Tariq, M.A., Blincoe, P., Mochel, M., Oswalt, S., Esser, T. (Eds.), (Organized by the California Department of Food and Agriculture), Proceedings of the Pierce's Disease Research Symposium, December 5-7, 2005, San Diego Mariott Hotel and Marina, San Diego, CA. Copeland Printing, Sacramento California, pp. 306-309.

de León, J.H., Jones, W.A., Morgan, D.J.W., 2003. Population genetic structure of the glassy-winged sharpshooter determined by ISSR-PCR DNA fingerprinting. In: Tariq, M.A., Oswalt, S., Blincoe, P., Spencer, R., Houser, L., Amadou, B., Esser, T. (Eds.), (Organized by the California Department of Food and Agriculture), Proceedings of the Pierce's Disease Research Symposium, December 9-11, 2003, Coronado Island Mariott Resort, San Diego, CA. Copeland Printing, Sacramento California, pp. 211-214.

de León, J.H., Jones, W.A., Morgan, D.J.W., 2004a. Population genetic structure of Homalodisca coagulata (Homoptera: Cicadellidae), the 
vector of the bacterium Xylella fastidiosa causing Pierce's disease in grapevines. Ann. Entomol. Soc. Am. 97, 809-818.

de León, J.H., Jones, W.A., Morgan, D.J.W., 2004b. Molecular distinction between populations of Gonatocerus morrilli, egg parasitoids of the glassy-winged sharpshooter Homalodisca coagulata, from Texas and California: do cryptic species exist? J. Insect Sci. 4 (39), 7. Available online: <insectscience.org/4.39>.

de León, J.H., Jones, W.A., 2005. Genetic differentiation among geographic populations of Gonatocerus ashmeadi (Hymenoptera: Mymaridae), the predominant egg parasitoid of Homalodisca coagulata (Homoptera: Cicadellidae). J. Insect Sci. 5 (2), 9. Available online: <insectscience.org/5.2>.

Felsenstein, J., 1985. Confidence limits on phylogenies: an approach using the bootstrap. Evolution 39, 783-791.

Gordh, G., Beardsley, J.W., 1999. Taxonomy and biological control. In: Bellows, Jr., T.S., Fisher, T.W. (Eds.), Handbook of Biological Control. Academic Press, San Diego, CA, pp. 45-56.

Hackett, B.J., Gimnig, J., Guelbeogo, W., Costantini, C., Koekemoer, L.L., Coetzee, M., Collins, F.H., Besansky, N.J., 2000. Ribosomal DNA internal transcribed spacer (ITS2) sequences differentiate Anopheles funestus and An. rivulorum, and uncover a cryptic taxon. Insect Mol. Biol. 9, 369-374.

Higgins, D.G., Sharp, P.M., 1988. CLUSTAL: a package for performing multiple sequence alignments on a microcomputer. Gene 73, 237-244.

Hopkins, D.L., 1989. Xylella fastidiosa: xylem-limited bacterial pathogen of plants. Annu. Rev. Phytopathol. 27, 271-290.

Hopkins, D.L., Mollenhauer, H.H., 1973. Rickettsia-like bacterium associated with Pierce's disease of grapes. Science 179, 298-300.

Huber, J.T., 1998. The species groups of Gonatocerus Nees in North America with a revision of the sulphuripes an ater groups (Hymenoptera: Mymaridae). Mem. Entomol. Soc. Can. 141, 1-109.

Jeyaprakash, A., Hoy, M.A., 2000. Long PCR improves Wolbachia DNA amplifications of $w s p$ sequences found in $76 \%$ of 63 arthropod species. Insect Mol. Biol. 9, 393-405.

Jukes, T.H., Cantor, C.R., 1969. Evolution of protein molecules. In: Munro, H.N. (Ed.), Mammalian Protein Metabolism. Academic Press, New York, pp. 21-132.

Karp, A., Edwards, J., 1997. DNA markers: a global overview. In: Caetano-Anolles, G., Gresshoff, P.M. (Eds.), DNA Markers-Protocols, Applications, and Overviews Wiley-Liss, Inc., New York, pp. 1-13.

Löhr, B.A., Varela, M., Santos, B., 1990. Exploration for natural enemies of the cassava mealybug, Phenococcus manihoti (Homoptera: Pseudococcidae), in South America for the biological control of this introduced pest in Africa. Bull. Entomol. Res. 80, 417-425.

Loxdale, H.D., Lushai, G., 1998. Molecular markers in entomology. Bull. Entomol. Res. 88, 577-600.

MacDonald, C., Loxdale, H.D., 2004. Molecular markers to study population structure and dynamics in beneficial insects (predators and parasitoids). Int. J. Pest Manag. 50, 215-224.

Messing, R.H., Aliniazee, M.T., 1988. Hybridization and host suitability of two biotypes of Trioxys pallidus (Hymenoptera: Aphidiidae). Ann. Entomol. Soc. Am. 81, 6-9.

Miller, D.R., Rossman, A.Y., 1995. Systematics, biodiversity, and agriculture. Bioscience 45, 680-686.

Moran, N.A., Dale, C., Dunbar, H., Smith, W.A., Ochman, H., 2003. Intracellular symbionts of sharpshooters (Insecta: Hemiptera: Cicadellinae) form a distinct clade with a small genome. Environ. Microbiol. 5, 116-126.

Narang, S.K., Tabachnick, W.J., Faust, R.M., 1993. Complexities of population genetic structure and implications for biological control programs. In: Narang, S.K., Barlett, A.C., Faust, R.M. (Eds.), Applications of Genetics to Arthropods of Biological Control Significance. CRC Press Inc., Boca Raton, FL, pp. 19-52.

Nielson, M.W., 1968. The leafhopper vectors of phytopathogenic viruses (Homoptera, Cicadellidae) taxonomy, biology, and virus transmission. USDA Tech. Bull. 1382, 81-84.

O’Neill, S.L., Giordano, R., Colbert, A.M.E., Karr, T.L., Robertson, H.M., 1992. 16S rRNA phylogenetic analysis of the bacterial endosymbionts associated with cytoplasmic incompatibility in insects. Proc. Natl. Acad. Sci. USA 89, 2699-2702.

Pinto, J.D., Stouthamer, R., Platner, G.R., Oatman, E.R., 1991. Variation in reproductive compatibility in Trichogramma and its taxonomic significance. Ann. Entomol. Soc. Am. 84, 37-46.

Porter, C.H., Collins, F.H., 1991. Species-diagnostic difference in a ribosomal DNA internal transcribed spacer from the sibling species Anopheles freeborni and Anopheles hermsi (Diptera: Culicidae). Am. J. Trop. Med. Hyg. 45, 271-279.

Redak, R.A., Purcell, A.H., Lopes, J.R.S., Blua, M.J., Mizell, R.F., Andersen, P.C., 2004. The biology of xylem fluid-feeding insect vectors of Xylella fastidiosa and their relationship to disease epidemiology. Annu. Rev. Entomol. 49, 243-270.

Roderick, G.K., 2004. Tracing the origins of pests and natural enemies: genetic and statistical approaches. In: Ehler, L.E., Sforza, R., Mateille, T. (Eds.), Genetics, Evolution, and Biological Control CABA International, Wallingford, UK, pp. 97-112.

Rosen, D., 1977. The importance of cryptic species and specific identifications as related to biological control. In: Romberger, J.A. (Ed.), Biosystematics is agriculture, Beltsville Symposium of Agricultural Research, Allanheld, Osmun, Monteclair, NJ, pp. 23-35.

Sambrook, J., Russell, D.W., 2001. Molecular Cloning: A Laboratory Manual, third ed. Cold Spring Harbor Laboratory Press, Cold Spring Harbor, New York.

SAS Institute, 2001. SAS user's guide, statistics. SAS Institute, Cary, NC.

Saitou, N., Nei, M., 1987. The neighbour-joining method: a new method for reconstructing phylogenetic trees. Mol. Biol. Evol. 4, 406-425.

Schauff, M.E., LaSalle, J., 1998. The relevance of systematics to biological control: protecting the investment in research. In: Pest ManagementFuture Challenges, vol. 1. Proceedings of the 6th Australian Applied Entomological Conference, Brisbane, Australia, September 29-October 2, 1998. pp. 425-436.

Sétamou, M., Walker, J.A., 2005. Biology and biometry of sharpshooter Homalodisca coagulata (Homoptera: Cicadellidae) reared on cowpea. Ann. Entomol. Soc. Am. 98, 322-328.

Simon, C., Frati, F., Bechenbach, A., Crespi, B., Liu, H., Flook, P., 1994. Evolution, weighting, and phylogenetic utility of mitochondrial gene sequences and a compilation of conserved polymerase chain reaction primers. Ann. Entomol. Soc. Am. 87, 651-701.

Smith, P.T., 2005. Mitochondrial DNA variation among populations of the glassy-winged sharpshooter, Homalodisca coagulata. J. Insect Sci. 5, 41 (available online: <insectscience.org/5.41>).

Sorensen, J.T., Gill, R.J., 1996. A range extension of Homalodisca coagulata (Say) (Hemiptera: Clypeorrhyncha: Cicadellidae) to southern California. Pan-Pac. Entomol. 72, 160-161.

Stouthamer, R., Breeuwer, J.A.J., Luck, R.F., Werren, J.H., 1993. Molecular identification of microorganisms associated with parthenogenesis. Nature 361, 66-68.

Swofford, D.L., 2002. PAUP*. Phylogenetic Analysis Using Parsimony (*and Other Methods), Version 4. Sinauer Associates, Sunderland, Massachusetts.

Thompson, J.D., Gibson, T.J., Plewniak, F., Higgins, D.G., 1997. The ClustalX windows interface: flexible strategies for multiple sequence alignment aided by quality analysis tools. Nucleic Acids Res. 24, 4876-4882.

Triapitsyn, S.V., Mizell III, R.F., Bossart, J.L., Carlton, C.E., 1998. Egg parasitoids of Homalodisca coagulata (Homoptera: Cicadellidae). Florida Entomol. 81, 241-243.

Turner, W.F., Pollard, H.N., 1959. Life histories and behavior of five insect vectors of phony peach disease. USDA Tech. Bull. 1188, 28.

Unruh, T.R., Woolley, J.B., 1999. Molecular methods in classical biological control. In: Van Driesche, R.G., Bellows, Jr., T.S. (Eds.), Biological Control. Chapman and Hall, NY, pp. 57-85.

Varela, L.G., Smit, R.J., Phillips, P.A., 2001. Pierce's Disease. University of California Agricultural Natural Research-Publication 21600 .

Werren, J.H., 1997. Biology of Wolbachia. Ann. Rev. Entomol. 42, 587-609. 
Werren, J.H., Windsor, D., 2000. Wolbachia infection frequencies in insects: evidence of a global equilibrium? Proc. Royal Soc. London B 267, 1277-1285.

Werren, J.H., Windsor, D., Guo, L., 1995. Distribution of Wolbachia among neotropical arthropods. Proc. Royal Soc. London B 262, 197-204.
Young, D.A., 1958. A synopsis of the species of Homalodisca in the United States (Homoptera: Cicadellidae). Bull. Brooklyn Entomol. Soc. 53, 7-13. Zietkiewicz, E., Rafalski, A., Labuda, D., 1994. Genomic fingerprinting by simple sequence repeat (SSR)-anchored polymerase chain reaction amplification. Genomics 20, 176-183. 